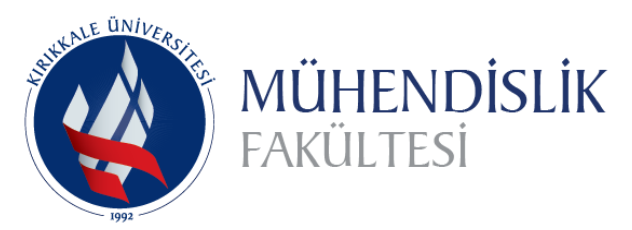
Uluslararası Mühendislik
Araştırma ve Geliştirme Dergisi UMAGD, (2022) 14(1), 347-359.
International Journal of
Engineering Research and
Development
10.29137/umagd.1032060

Cilt/Volume:14 Sayı/Issue:1 Ocak/January 2022

Araştırma Makalesi / Research Article

\title{
Negatif Poisson Oranına Sahip Sandviç Kompozitlerin Statik Davranışının Belirlenmesi
}

\section{Determination of Static Behavior of Sandwich Composites with Negative Poisson Ratio}

\author{
Munise Didem Demirbaş ${ }^{1}$ iD, Onur Demir $^{2}$ iD \\ ${ }^{1}$ Erciyes Üniversitesi, Makine Mühendisliği Bölümü, Kayseri, TÜRKIYE
}

Başvuru/Received: 04/12/2021

Kabul / Accepted: 21/01/2022

Çevrimiçi Basım / Published Online: 31/01/2022

Son Versiyon/Final Version: 31/01/2022

\begin{abstract}
$\ddot{\mathbf{O} z}$
Bu çalışmada, mühendislik malzemesi olarak pek çok yeni araştırmanın konusu olan negatif poisson oranına sahip yapıların statik davranışı sayısal olarak belirlenmiştir. Al plakalar arasına ABS ve PLA çekirdek malzemelerinin yerleştirilmesiyle oluşturulan sandviç kompozit yapılar, negatif poisson oranına sahip yapıyla modellenmiştir. Ayrıca kompozit malzemelerin kıyaslanması için sandviç malzeme bileşenlerinin de aynı şartlar altında analizleri yapılmıştır. Statik analizler Ansys Workbench programı ile araştırılmıştır. Statik tesir altında tüm kompozisyonlarda çekirdek geometrisine bağlı olarak negatif poisson oranına uygun davranış gözlenmiştir. PLA çekirdek malzemesine sahip sandviç kompozit yapıda en düşük yer değiştirme ve gerilme seviyeleri elde edilmiştir.
\end{abstract}

\section{Anahtar Kelimeler}

"Kompozit malzemeler, Negatif Poisson oranı, statik analiz"

\begin{abstract}
In this study, the static behavior of structures with negative Poisson's ratio, which was the subject of many new researches as engineering materials, was determined numerically. The sandwich composite structures formed by placing ABS and PLA core materials between the Al plates were modeled with a negative Poisson ratio structure. In addition, for the comparison of the composite material, the analysis of the sandwich material components was carried out under the same conditions. Static analyzes were investigated with the Ansys Workbench program. A negative Poisson ratio behavior was observed in all compositions under the static influence, depending on the core geometry. The lowest displacement and stress levels were obtained in the sandwich composite structure with PLA core material.
\end{abstract}

Key Words

"Composite materials, Negative Poisson's ratio, static analysis" 


\section{Giriş}

Mühendislik alanında üst düzey gelişmeler günümüzde daha mukavemetli, aynı zamanda daha hafif yapı ve malzemelerin oluşmasını sağlamaktadır. Bu yapılara kompozit malzeme yapılarını örnek verebiliriz. Kompozit malzeme iki veya daha fazla bileşenden meydana gelen malzemelerdir. Bu bileşenler makroskobik seviyede bir araya getirilirler ve birbirleri içinde çözünmezler. Takviye elemanı olarak adlandırılan bileşen; fiber, partikül veya ince levha şeklinde olabilir. Diğer bileşen ise matris fazıdır (Ceyhun ve Turan, 2003). Bu malzemeler daha dayanımlı olmasının yanında hafif olmaları mühendislikte büyük öneme sahiptir. Son zamanlarda doğadan esinlenerek, tek eksenli bir yükleme hali için yanal ile eksenel şekil değiştirme oranının aynı işaretli olması yani negatif Poisson oranına sahip olması durumu çalışmalara konu olmaktadır. Literatürde, Poisson oranı, tek eksenli bir şekil değiştirme hali için yanal ile eksenel şekil değiştirme oranının negatif işaretlisi olarak tanımlanır ve daima pozitiftir (Korkut, 2019). Negatif poisson oranlı malzemelere auxetic malzemeler denilmektedir. Auxetic malzemeler kuvvet etkisi altında basma tesirinde daralan, çekme tesirinde ise genişleyen malzemelerdir. Auxetic malzemelerin geometrik yapılarından dolayı açığa çıkan; yüksek enerji absorbe yeteneği, sürtünme dayanımı, hafiflik, kopma dayanımı vb. avantajlar göz önünde bulundurulduğu zaman mühendislik alanında verimli olabileceği düşünülmektedir.

Araştırmalar göz önünde bulundurulduğunda, negatif poisson oranına sahip yapıların sandviç kompozit yapılara dahil edilmesi ile kullanım amacına uygun olarak verimli malzeme bileşimi oluşturulabileceği düşünülmektedir.

\subsection{Literatür Araştırması}

Mühendislik yapılarında meydana gelebilecek hataları önceden tahmin edip bu hatalar doğrultusunda tasarım ve analiz yapmak çok büyük öneme sahiptir. Ani darbe sonucu oluşan kalıcı deformasyonlar geçmişten günümüze önemli sorunlara sebep olmaktadır. Kuvvet veya ani darbe sonucunda malzemelerde oluşabilecek enerji değişimi ve yetersiz sürtünme dayanımı kalıcı deformasyonlara yol açabilmektedir. Bu olumsuz etkileri önlemek açısından bu çalışmada; Al plakalar arasına ABS ve PLA çekirdek yapıların yerleştirilmesiyle oluşturulan sandviç kompozit yapıların, negatif poisson oranına sahip yapıyla modellenmesi ele alınmıştır. Bu yapılar yüksek mukavemet/ağırlık oranı, yüksek enerji sönümleme ve yüksek eğilme momenti gibi özelliklere sahiptir. Matris malzemenin ve takviye malzemesinin özellikleri, bu fazların birbirlerine yapışma kabiliyeti ve takviye malzemesinin yapı içindeki dizilişi bu kompozit malzemelerin özelliklerini belirlemektedir. (Potoğlu, 2012).

Sandviç kompozitlerin ortasında çok hafif ama mukavemeti düşük, üst ve alt kısmında ise kabuk olarak adlandırılan daha ince fakat mukavemeti yüksek malzemeler (Al, cam, aramid veya karbon gibi) yer alır. Bu tür kompozit malzemelerde ortada ara malzeme (veya çekirdek) olarak kullanılan malzemeler genellikle çeşitli köpükler (PVC, PET), balsa ağacı ve bal peteği formundaki Al veya termoplasikten yapılmaktadır (Potoğlu, 2012).

Kompozit malzemeler, yüksek elastik modül ve yüksek özgül mukavemet avantajlarından dolayı, havacılık ve gemi sanayisinde tercih sebebidir. Özellikle tekrarlı yüklere maruz kalan malzemelerin yorulma hasarı davranışı doğru tanımlanmalıdır. Kompozit malzemeler hasarı bünyelerinde depolarlar ve hasar her zaman makroskobik bir hasarla meydana gelmez. Fiber hasarı, ayrılma, ters yönlü tabaka çatlağı ve matris çatlağı gibi hasar türleri oluşabilmektedir (Imak vd., 2016 ).

Malzemenin karakteristik özelliklerinden biri Poisson oranıdır. Poisson oranının tanımı şu şekilde yapılmaktadır: Bir malzemeye uygulanan kuvvetin dik doğrultusunda oluşan birim şekil değiştirme ile kuvvetin uygulandığg doğrultudaki birim şekil değiştirme oranı Poisson oranıdır. En basit tanımlamayla Poisson oranı bir malzemenin basınç altında ne kadar daraldığının ya da genişlediğinin matematiksel değeridir (Işıltan, 2017).

Günümüzde kullanım alanlarında sağladığı farklı mekanik özellikler nedeni ile farklı Poisson oranına sahip malzemeler tasarlanmaktadır. Bu kapsamda gün geçtikçe artan bir çalışma konusu olan ve farklı mekanik özelliklerinden faydalanmak için tasarlanan negatif poisson orana sahip malzemeler bulunmaktadır. $\mathrm{Bu}$ malzemeler mekanik meta malzemeler olarak isimlendirilmektedir (Uzun 2017). Mekanik meta malzemeler, özelliklerini kimyasal yapılarından değil fiziksel yapılarından türeten, doğada ve kendisini oluşturan malzemelerde gözlemlenmeyen özellikler sergileyen malzemelerdir. Bu özellikleri nedeni ile mekanik meta malzemeler, dâhili mikro yapılarının programlanmış bir tasarımı ile ayarlanabilmektedir (Yu vd., 2018). Mikro-yapılı meta malzemelerin geleneksel işleme teknikleri kullanılarak üretilmesi daha önceleri zor olmakta iken, son zamanlarda gelişmiş 3B baskı tekniklerinin ortaya çıkması üretim noktasından yaşanan engelleri ortadan kaldırmıştır (Jiang ve Li, 2018).

Mekanik bir meta malzemede gözlemlenen negatif poisson oranı, hücre tasarımlarına göre farklılık göstermektedir. Yapılan mekanik meta malzeme tasarımları sayesinde çok geniş bir aralıkta uyarlanabilir olmaktadır (Berwind vd., 2018). Bu alanda yapılan en eski çalışmalarda, Re-entrant olarak adlandırılan yapısal hücre tasarımına sahip mekanik meta malzeme kullanılmış ve -0.7 negatif poisson oranına sahip bir meta malzeme bildirmiştir (Lakes, 1987).

Negatif Poisson oranın sahip malzemeler pozitif Poisson oranına sahip malzemelerin tersine olağanüstü bir özellik olarak gerildikçe genişlerler ve basıldıkça daralırlar. Bu özellik geçen yüzyıldan beri bilinmesine rağmen mekanik ve mantık olarak anlaşılması ve malzemelere uygulanması 1980'li yıllarda başlanmıştır. İlk olarak 1987 yılında Rod Lakes tarafında Science dergisinde negatif Poisson oranına sahip “foam” yapılar yayınlanmıştır (Uzun, 2017). 
Ayrıca meta malzeme hücresel tasarımına sahip sandviç yapıların, yapısal tepkileri, kırılma mekanizmaları, burkulma davranışı, darbe ve enerji soğurma yetenekleri bir auxetic hücresel çekirdekten yapılan muadilleriyle karşılaştırıldığında; Re-entrant meta malzemeden üretilmiş çekirdeğe sahip sandviç yapıların, çekirdek topolojisinin ve geometrik parametrelerinin, kırılma mekanizmaları ve enerji soğurma yetenekleri üzerinde önemli rol oynadığı bulunmuştur (Sarvestani vd., 2018). Tasarlanan meta malzemelerden üretilmiş çekirdeğe sahip sandviç yapılar, hem geliştirilmiş̧ enerji soğurma özelliğine hem de önemli derecede hafiflik sağlayacaktır (Yuan vd., 2019).

Re-entrant peteğine temel alınarak geliştirilmiş negatif poisson oranına sahip petek tasarımı yapılan bir başka çalışmada iç çeper birleşim yerleri modifiye edilerek hibrit bir yapı oluşturulmuş ve 3B yazıcı kullanarak alınan numuneler üzerinde testler yapılmıştır. Çalışmada kullanılan hibrit yapıların yüksek enerji emici mekanik özelliklere sahip oldukları görülmüştür (Ingrole vd., 2017). Bal peteği ve Re-entrant yapılar ile yeni elde edilen hibrit yapıların geometrileri aşağıda gösterilmiştir (Şekil 1.).
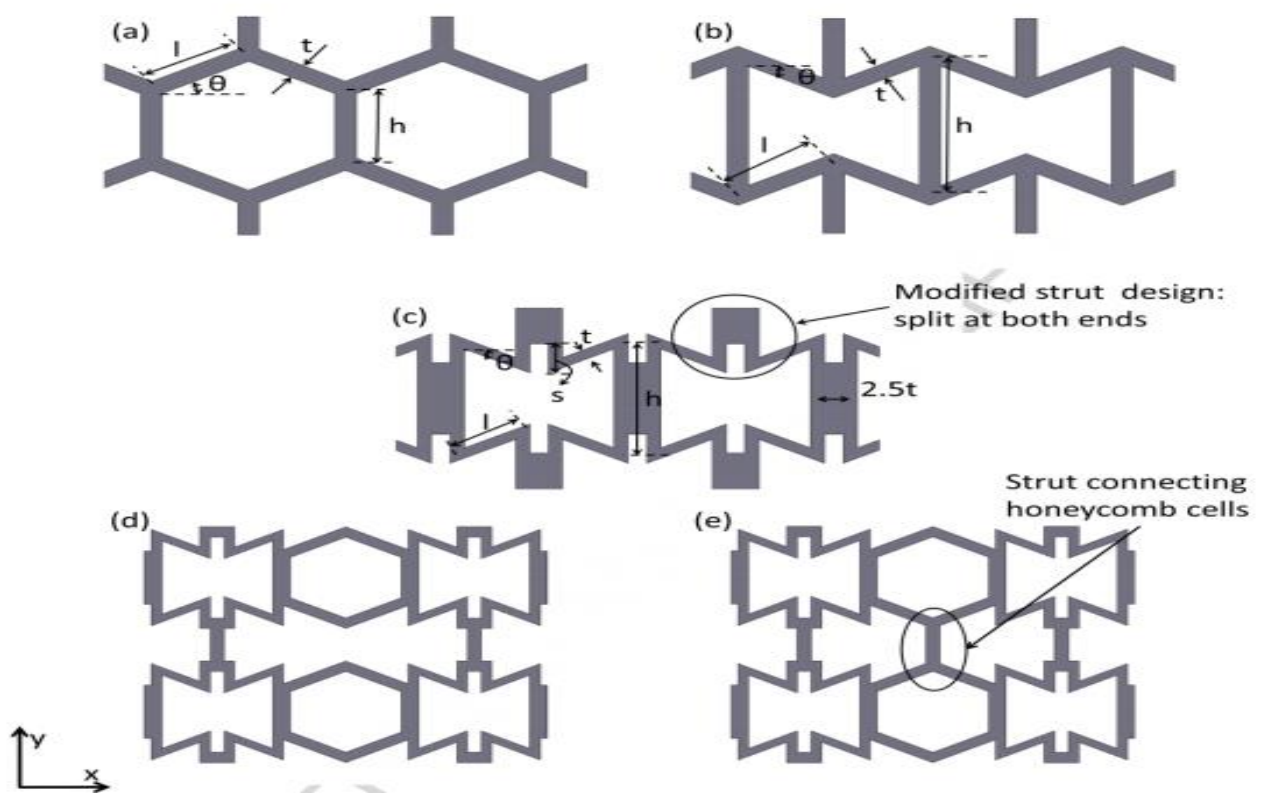

Şekil 1. Birim hücre tasarımları (a) bal peteği, (b) re-entrant auxetic, (c) auxetic-struts, (d) auxetic-honeycomb1 (AH-V1) hibrit yapı, ve (e) auxetic -honeycomb2 (AH-V2) hibrit yap1 (Ingrole vd., 2017).

Negatif Poisson oranına sahip malzemeler ile ilgili 3B yazıcılarda kullanılabilen malzemeler düşünülerek araştırmalar yapılmaktadır. 3B yazıcılarda aktif olarak kullanılabilen çekirdek malzemeleri ise Akrilonitril bütadien stiren (ABS) ve Poliaktik Asit (PLA)'dir. ABS plastik darbelere karşı direnci yüksek olan ve dayanaklı gövdelerde kullanılan hafif bir malzemedir. PLA plastik petrol bazlı olmayan sert ve düşük genleşme katsayısına sahip bir bio malzemedir (Dirim, 2021).

3D baskı teknolojisi, havacıllk endüstrisinde, birçok tıbbi aletin hafif ve karmaşık yapısal modellenmesinde, üretiminde ve prototiplenmesinde kullanılan bir eriyik birikim modelleme (FDM) yöntemidir. Polilaktik asit (PLA), toksik olmaması, biyolojik olarak parçalanabilirliği, endüstriyel tasarımlar ve tıbbi uygulamalar için kolay üretilebilirliği nedeniyle 3D yazıcılarda hammadde olarak kullanılmaktadır (Boğa vd.,2021).

ABS plastiklerinin avantajları; dayanıklı, kolay işlenebilir ve kimyasal direnci çok iyi olan polimer malzemedir. ABS, Geniş bir sicaklık aralığında kullanılmasının yanı sıra su buharına karşı mükemmel bir bariyerdir. Bariyer özelliği yoğunluğun artmasıyla birlikte artan kristalik derecesi, dayanıklık, sertlik ve erime sıcaklığına bağlı olarak artış gösterir (Şen vd., 2020).

Yenilenebilir kaynaklardan üretilen biyolojik olarak çözünebilir bir polyester olan PLA, çeşitli uygulamalar (biyomedikal, ambalaj, tekstil elyafları ve teknik ürünler) için kullanılmaktadır. Özellikleri nedeniyle PLA, biyopolimerler pazarında önemli bir yere sahiptir ve gelecekteki kullanım olanaklarına bakıldığında en umut verici biyopolimer adaylarından biridir. PLA'nın farklı uygulamalar için özelliklerinin geliştirilmesi gerekmektedir. Bu nedenle, PLA matrisi içine takviye edici liflerin, mikro ve/veya nano dolgu maddelerinin ve seçilen katkı maddelerinin eklenmesi ile istenen son kullanım özelliklerinde büyük iyileştirmeler elde edilmesi mümkün görünmektedir (Ermeydan ve Aykanat, 2019).

Ayrıca alüminyum ve alaşımları, takviye malzemeleri ile fiziksel ve kimyasal uyumluluk, hafiflik, düşük yoğunluk, yüksek elektrik, yüksek ısı iletkenliğine sahip olmaları ve geniş uygulama alanları nedeniyle metal matrisli kompozitlerde matris malzemesi olarak 
tercih edilmektedirler (Öztop ve Gürbüz, 2017). Bu nedenle sandviç kompozit yapıda ABS ve PLA çekirdek katmanın alt ve üst kısmında kabuk olarak alüminyum ve alaşımları seçilmesi uygun niteliktedir.

\section{Malzeme ve Metot}

\subsection{Sandviç Kompozit Yapılar}

Kompozit malzemeler; üstün avantajlara sahip olan, devamlı gelişim gösteren ve yeni yapıların oluşmasına imkan tanıyan bir olgudur. $\mathrm{Bu}$ gelişimlerden doğan yapıların en önemlilerinden biri Sandviç kompozit yapılardır. Literatürde yer alan bilgiler göz önünde bulundurulduğunda; bu şekilde bir yapıyla, darbelere karşı enerji absorbsiyonu sağlanarak yüksek dayanım elde etmek mümkün olabilmektedir.

$\mathrm{Bu}$ çalışmada; 2 katmanlı 3'er mm kalınlığında $\mathrm{Al}$ arasına $4 \mathrm{~mm}$ kalınlığında ABS ve PLA (3mmAl-4mmABS-3mmAl/3mmAl4mmPLA-3mmAl) malzemelerinin ayrı ayrı yerleştirilmesi sonucu, kuvvet etkisi altında her bir yapıda oluşan statik davranış incelenmiş̧ir. Model olarak negatif poisson etkisi gösteren geometriye sahip bir modelleme yapılmıştır.

\subsection{Auxetic Malzemeler (Negatif Poisson Oranlı Malzemeler)}

Poisson oranını kısaca ve basitçe ifade etmek gerekirse; bir malzemeye kuvvet uygulanması sonucunda, malzemenin yanal şekil değiştirmenin, boyuna şekil değiştirmeye oranı olarak tanımlayabiliriz. Eş.(1), Poisson oranı formülünü göstermekte olup sırasıyla $\varepsilon_{\text {yanal }}, \varepsilon_{\text {eksenel }}$ yanal ve eksenel şekil değişimlerini göstermektedir.

$$
v=-\frac{\varepsilon \text { yanal }}{\varepsilon_{\text {eksenel }}}
$$

Auxetic malzemeler ise, poisson oranının aksine basma etkisinde daralma ve çekme etkisinde genişleme sağlayarak negatif poisson oranlı bir davranış sergilemektedir. Bu davranış neticesinde, üstün sürtünme dayanımı ve kopma dayanımı göstermektedir.

\subsection{Malzemelerin Mekanik Özellikleri}

Tablo 1, bu çalışmada kullanılan; Al, ABS, PLA malzemelerinin mekanik özelliklerini göstermektedir.

Tablo 1. Malzemelerin Mekanik Özellikleri

\begin{tabular}{|c|c|c|c|}
\hline \multirow[b]{2}{*}{ Özellikler } & \multicolumn{3}{|c|}{ Malzemeler } \\
\hline & Al & ABS & PLA \\
\hline Yoğunluk $\left(\mathrm{kg} / \mathrm{m}^{3}\right)$ & 2770 & 1040 & 1250 \\
\hline Young Modülü (Pa) & $7,1^{10}$ & $2,39^{09}$ & $3,45^{09}$ \\
\hline Poisson Oranı (Pa) & 0,33 & 0,399 & 0,39 \\
\hline Bulk Modülü (Pa) & $6,9608^{10}$ & $3,9439^{09}$ & $5,2273^{09}$ \\
\hline Kayma Modülü (Pa) & $2,6692^{10}$ & $8,5418^{08}$ & $1,241^{09}$ \\
\hline Akma Mukavemeti (Pa) & $2,8^{08}$ & $4,14^{07}$ & $5,41^{07}$ \\
\hline $\begin{array}{l}\text { Maksimum Çekme } \\
\text { Mukavemeti }(\mathrm{Pa})\end{array}$ & $3,1^{08}$ & $4,43^{07}$ & $5,92^{07}$ \\
\hline
\end{tabular}




\section{Modelleme ve Analiz}

Negatif poisson orana sahip yapı, bilgisayar destekli tasarım programlarından SolidWorks ile gerçekleştirilmektedir. SolidWorks ile auxetic katı modellemesi yapılan parça daha sonra sonlu elemanlar yöntemi programlarından Ansys Workbench'e aktarılarak yukarıda belirtilen sandviç kompozit yapı oluşturulmuştur. Daha sonra kuvvet etkisi altındaki statik sonuçlar incelenecektir.

\subsection{Katı Modelleme}

Şekil 2. Re-entrant hexagon geometrik yapıya sahip negatif poisson oranlı davranış gösteren katı modellemeyi göstermektedir. Modelleme bilgisayar destekli tasarım programlarından SolidWorks ile gerçekleştirilmektedir. 90x48.35x10 mm ölçekli model hem ekstrüzyon hem de düzlemsel yüzey olarak katı ve yüzey oluşturma yöntemiyle gerçekleştirilmektedir.
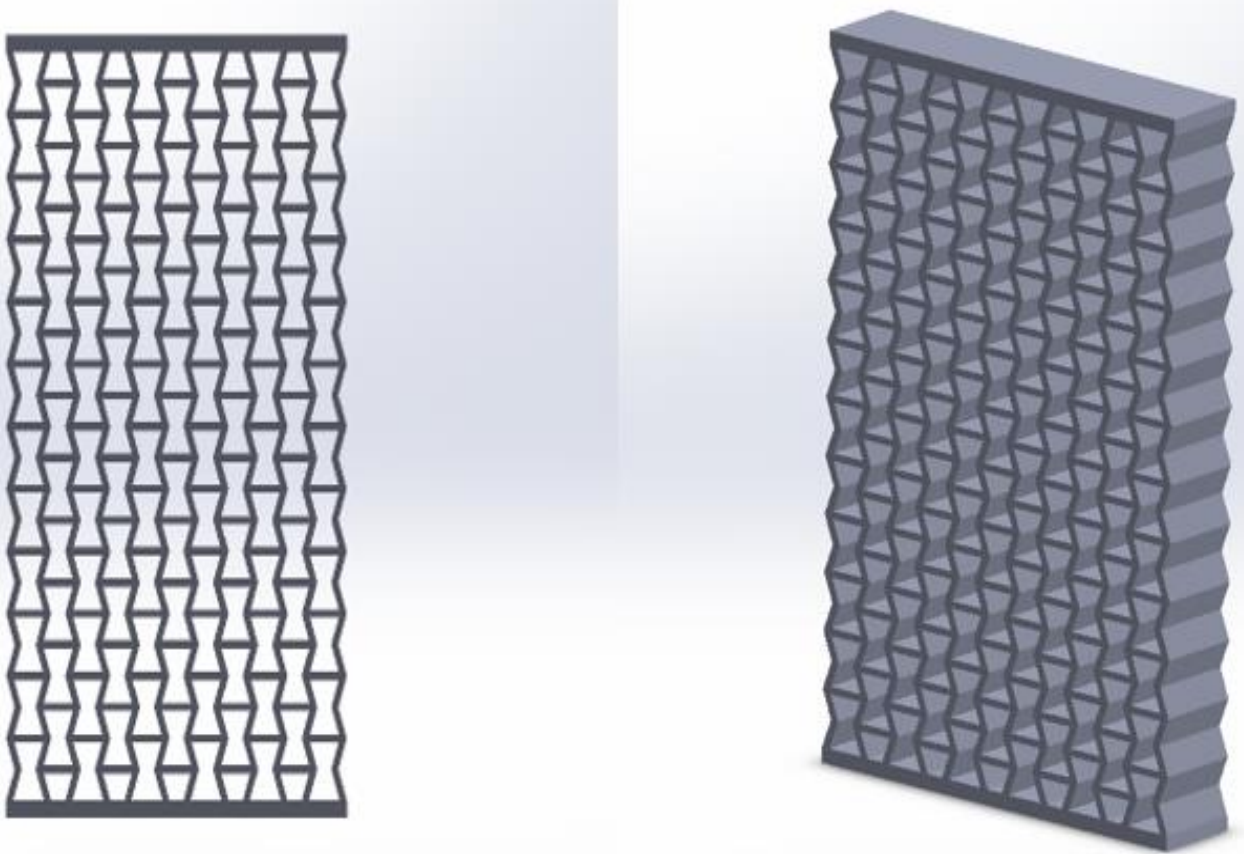

Şekil 2. Re-entrant hexagon geometri yapı katı model (90x48,35x10 mm)

\subsubsection{Kompozit modelleme}

Şekil 3'de, Re-entrant hexagon geometrik yapıya entegre edilen sandviç kompozit yapı modeline yer verilmektedir. Bu model, üç katmandan oluşmakta olup Şekil 3'de gösterilen 2 adet 3mm kalınlığında Al katman arasına, 1 adet 4mm kalınlığında ABS veya PLA katmanı yerleştirilerek oluşturulmaktadır.

Şekil 3'de görülen modelleme ile beş farklı problem incelenecektir. Al-Al-Al, ABS-ABS-ABS, PLA-PLA-PLA, 3mm Al-4mm ABS$3 \mathrm{~mm}$ Al ve $3 \mathrm{~mm} \mathrm{Al-4mm} \mathrm{PLA-3mm} \mathrm{Al} \mathrm{şeklinde} \mathrm{oluşturulan} \mathrm{katmanlar} \mathrm{ayrı} \mathrm{ayrı} \mathrm{analiz} \mathrm{edilecektir.}$ 


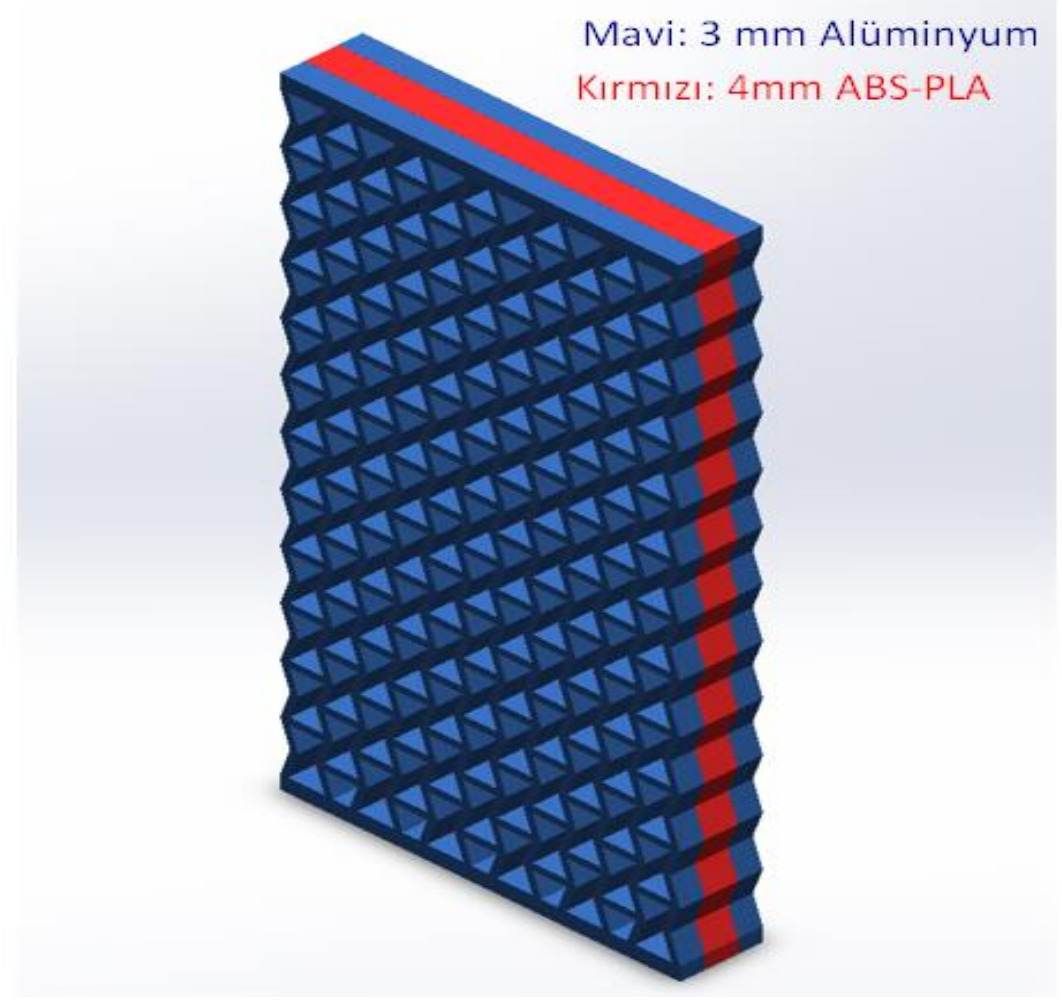

Şekil 3. Re-entrant hexagon model de sandviç kompozit katmanları (Mavi: 3mm Al / Kırmızı: 4mm ABS-PLA)

\subsection{Analiz}

Şekil 2'de, katı modellemesi gösterilen Re-entrant hexagon geometrik yapının statik analizleri sonlu elemanlar yöntemi (FEM) programlarından Ansys Workbench ile gerçekleştirilmiştir. SolidWorks'de parasolid uzantılı kaydedilen model Ansys Workbench'e aktarılmıştır. Sandviç kompozit yapı oluşturmak için ACP (PRE) kullanılmıştır. ACP içerisinden tasarımı yapılan modelin kompozit katmanları oluşturulmuştur.

$\mathrm{Bu}$ çalışmada, beş farklı malzeme dağılımı konfigürasyonu ele alınmıştır. İlk konfigürasyonda \%100 Al'dan oluşan model, ikincide, \% 100 ABS'den oluşan model, üçüncüde, \% 100 PLA'dan oluşan model, dördüncüde ise, 3 katmanlı; 3mm Al-4mm ABS-3mm Al sandviç kompozit yapı, son olarak da 3 katmanlı; $3 \mathrm{~mm}$ Al-4mm PLA-3mm Al sandviç kompozit yapı konfigürasyonları için y ekseninden 1000 N'luk kuvvet uygulanmış ve statik davranışı araştırılmıştır. Yapıların yer değiştirme $(\mathrm{mm})$ ve eşdeğer gerilme (MPa) dağılımları incelenmiş ve farklı malzeme dağılımları için elde edilecek sonuçlar karşılaştırılmıştır.

Negatif poisson oranı tesirindeki davranışın net bir şekilde görülmesi açısından analizler beş kat büyütülerek gösterilmektedir. Böylece basma kuvveti etkisi altında iç içe geçen geometrik yapı ve çekme kuvveti etkisi altında genişleyen geometrik yapı daha anlaşılır şekilde simüle edilmektedir.

\subsection{1. $\% 100 \mathrm{Al}$}

Şekil 4'de, \%100 Al ile oluşturulan a) -y ve b) +y yönünde uygulanan 1000 N'luk kuvvet tesirindeki yapının statik analiz sonuçları görülmektedir. Burada lineer geometrik diziliş ve Re-entrant hexagon yapı itibariyle modelde basma kuvveti etkisi altında daralma görülmektedir. Yer değiştirme tesirinde yapı auxetic davranış sergilemektedir. En küçük gerilmeler ise, hücrelerin orta kısımlarındaki birleşim bölgelerinde oluşmaktadır. Şekil 4'de alt kısımda yer alan yer değiştirme ve gerilme dağılımlarında, çekme kuvveti etkisiyle yanal genişleme meydana gelmektedir. Böylece yapı çekme tesirinde auxetic davranışa uygun sonuçları vermektedir. 
a)

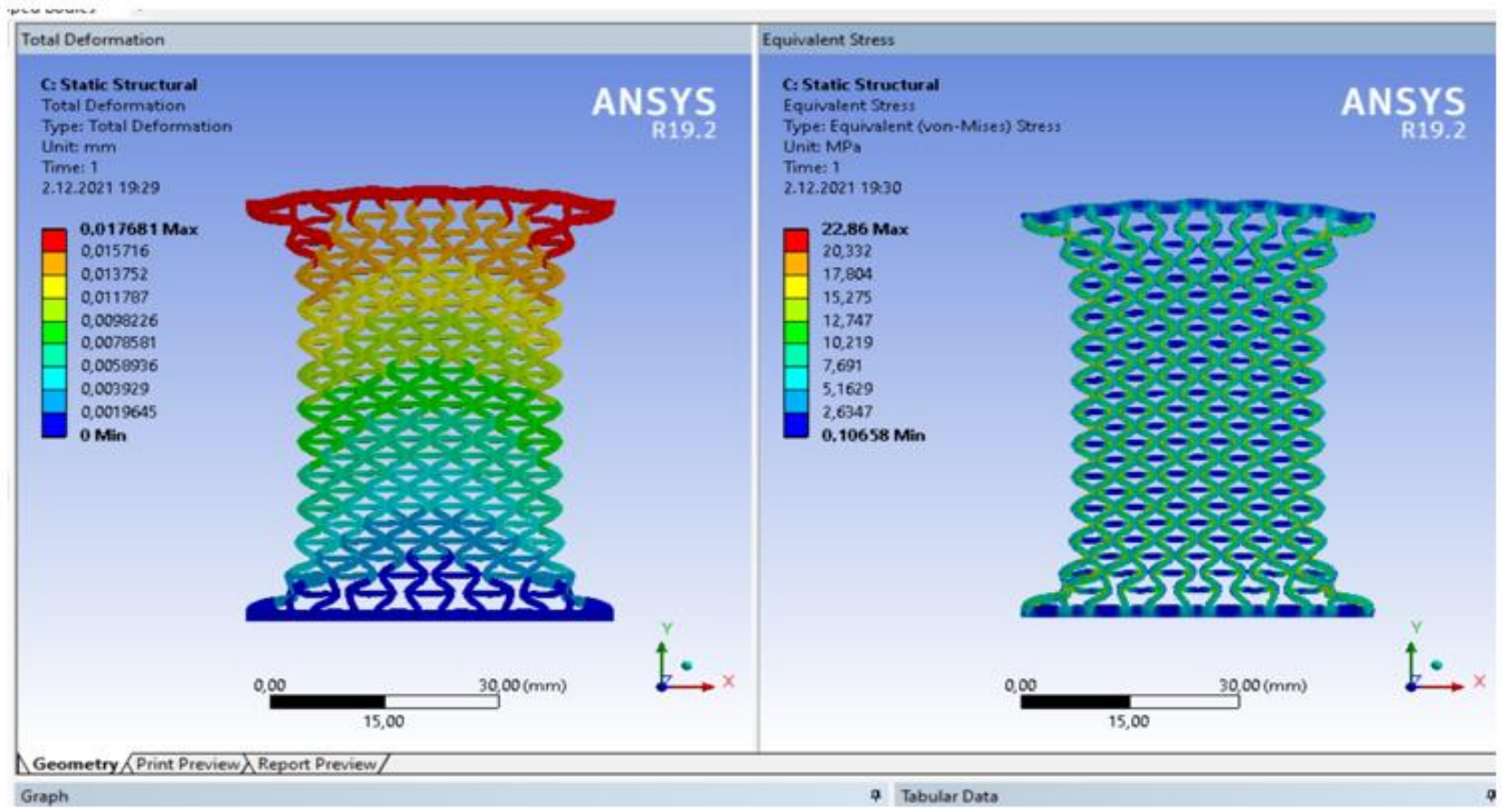

b)

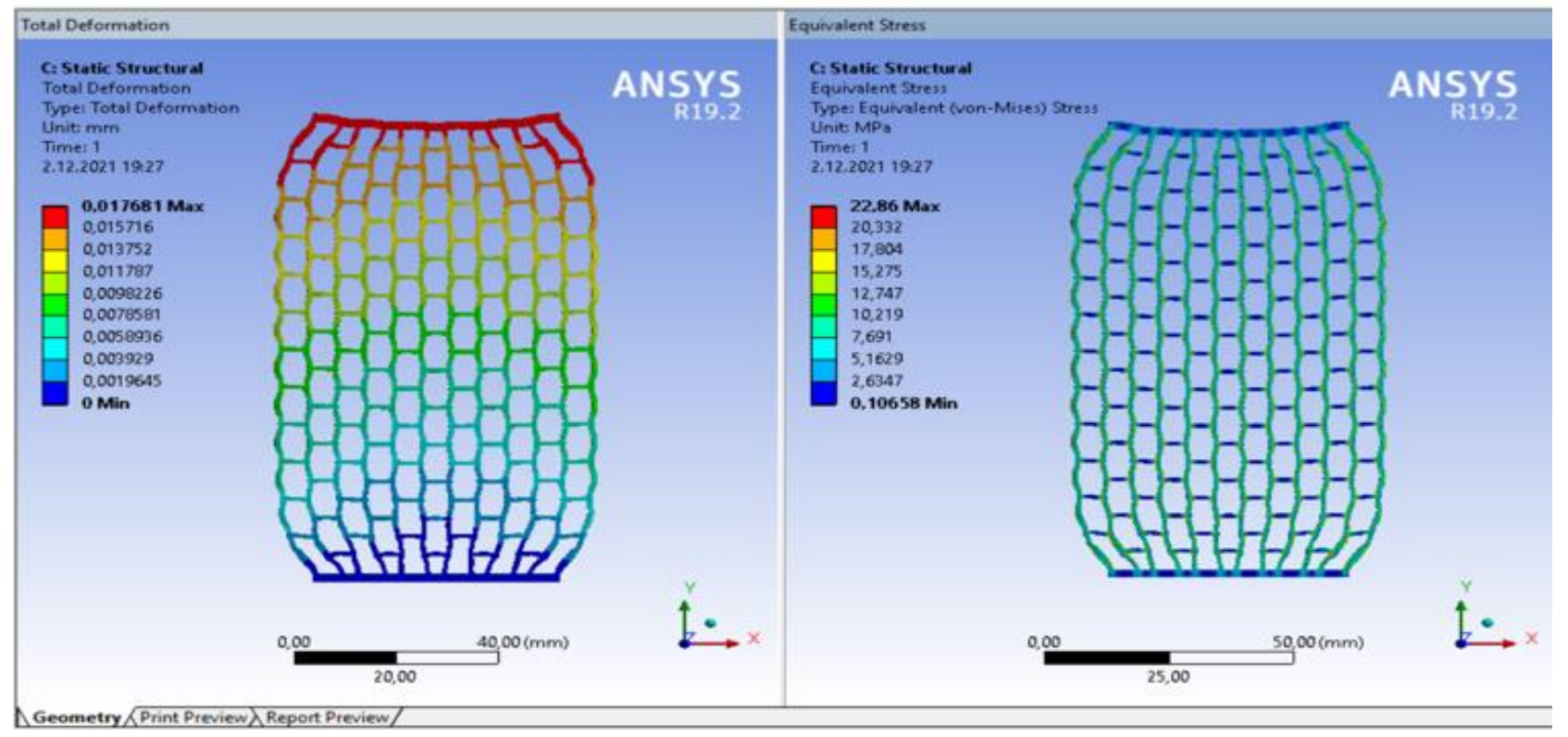

Şekil 4. Eksenel $1000 \mathrm{~N}$ kuvvet etkisindeki sırasıyla a) basma ve b) çekme tesirindeki \%100 Al olan model için analiz sonuçları

\subsection{2. $\% 100 A B S$}

Şekil 5'de, \%100 ABS ile oluşturulan a) -y ve b) +y yönünde uygulanan 1000 N'luk kuvvet tesirindeki yapının statik analiz sonuçları görülmektedir. Burada lineer geometrik diziliş ve Re-entrant hexagon yapı itibariyle modelde basma kuvveti etkisi altında daralma görülmektedir. Yer değiştirme tesirinde yapı auxetic davranış sergilemektedir. En küçük gerilmeler ise, hücrelerin orta kısımlarındaki birleşim bölgelerinde oluşmaktadır. Şekil 5'de alt kısımda yer alan yer değiştirme ve gerilme dağılımlarında, çekme kuvveti etkisiyle yanal genişleme meydana gelmektedir. Böylece yapı çekme tesirinde auxetic davranışa uygun sonuçları vermektedir. 
a)

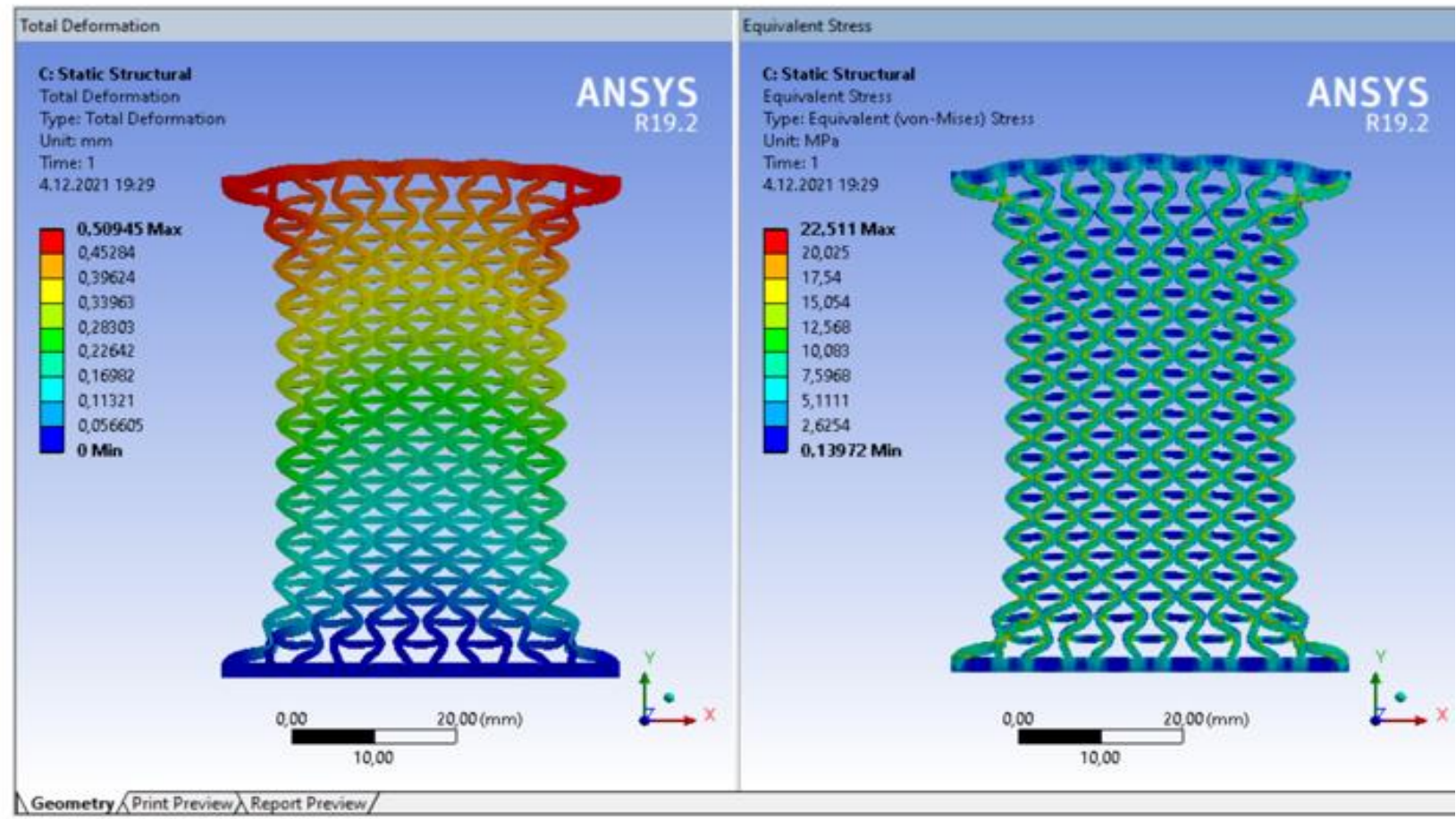

b)

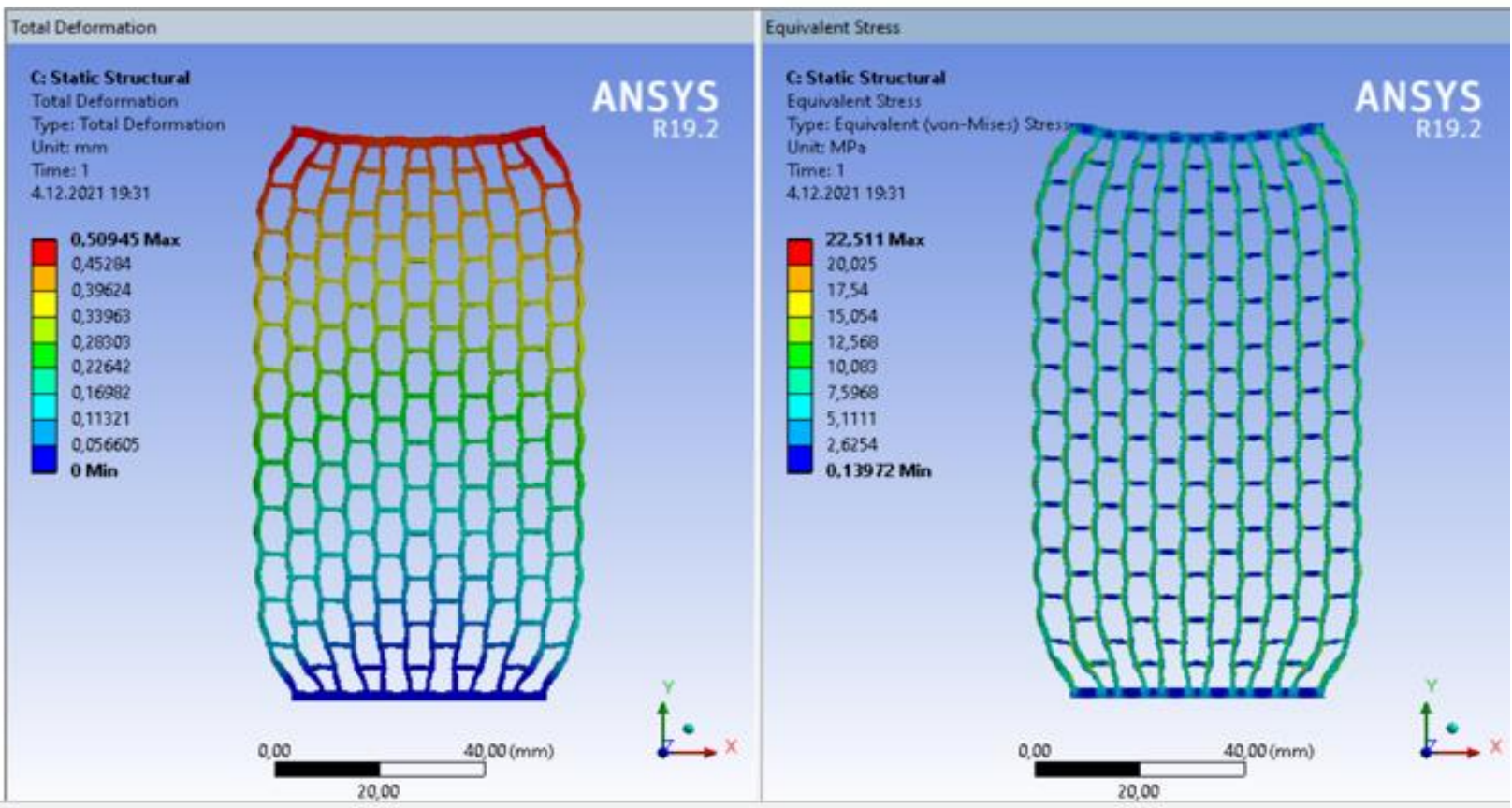

Şekil 5. Eksenel $1000 \mathrm{~N}$ kuvvet etkisindeki sırasıyla a) basma ve b) çekme tesirindeki \%100 ABS olan model için analiz sonuçları

\subsection{3. \% 100 PLA}

Şekil 6'da, \%100 PLA ile oluşturulan a) -y ve b) +y yönünde uygulanan 1000 N'luk kuvvet tesirindeki yapının statik analiz sonuçları görülmektedir. Burada lineer geometrik diziliş ve Re-entrant hexagon yapı itibariyle modelde basma kuvveti etkisi altında daralma görülmektedir. Yer değiştirme tesirinde yapı auxetic davranış sergilemektedir. En küçük gerilmeler ise, hücrelerin orta kısımlarındaki birleşim bölgelerinde oluşmaktadır. Şekil 6'da alt kısımda yer alan yer değiştirme ve gerilme dağılımlarında, çekme kuvveti etkisiyle yanal genişleme meydana gelmektedir. Böylece yapı çekme tesirinde auxetic davranışa uygun sonuçları vermektedir. 
a)

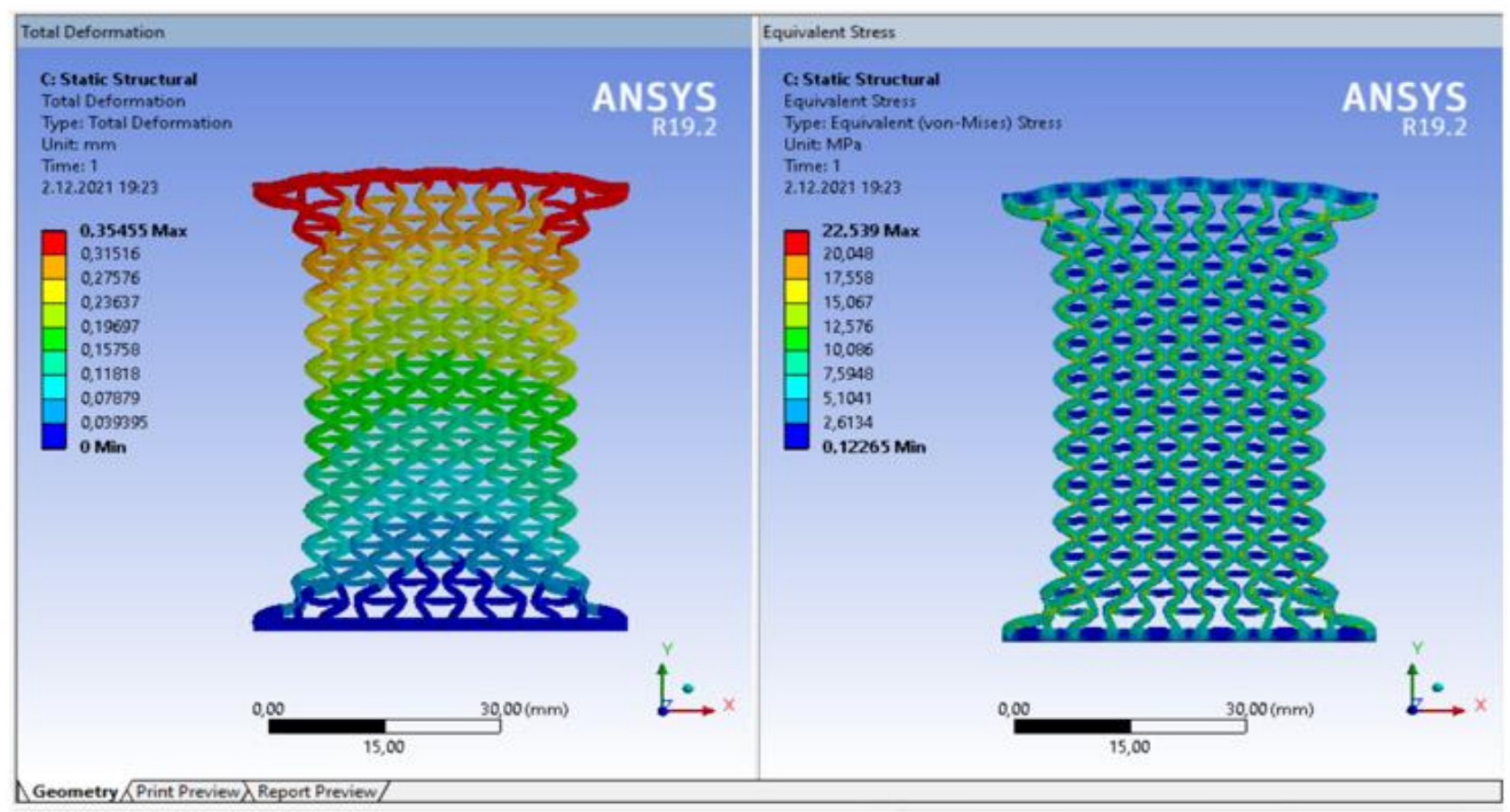

b)

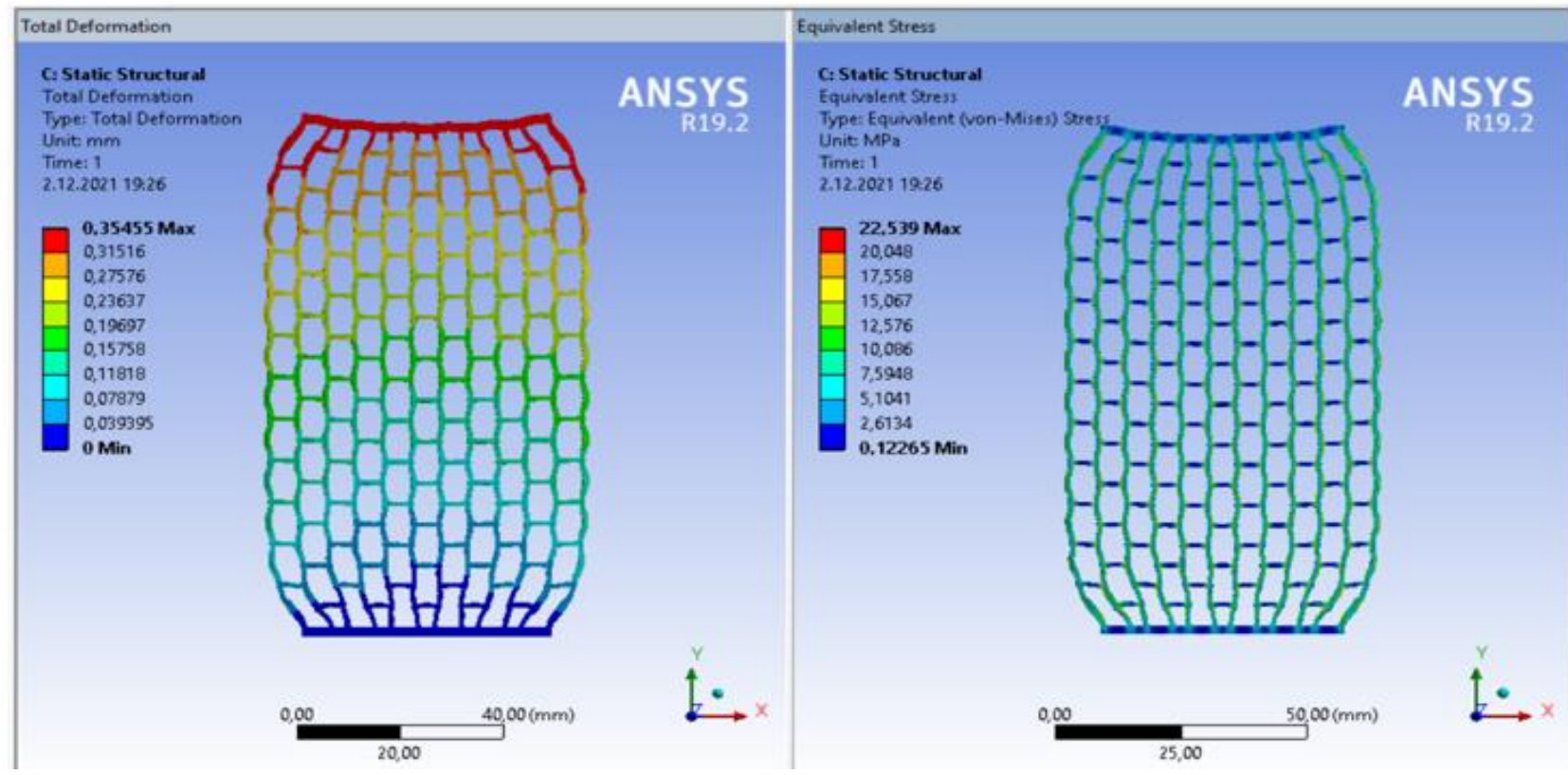

Şekil 6. Eksenel $1000 \mathrm{~N}$ kuvvet etkisindeki sırasıyla a) basma ve b) çekme tesirindeki \%100 PLA olan model için analiz sonuçları

\subsection{4. $3 \mathrm{~mm} \mathrm{Al-4} \mathrm{mm} \mathrm{ABS-3} \mathrm{mm} \mathrm{Al} \mathrm{model}$}

Şekil 7'de, 3 mm Al-4 mm ABS-3 mm Al sandviç kompozit yapının a) -y ve b) +y yönünde uygulanan 1000 N'luk kuvvet tesirindeki statik analiz sonuçları görülmektedir. Burada lineer geometrik diziliş ve Re-entrant hexagon yapı itibariyle modelde basma kuvveti etkisi altında daralma görülmektedir. Yer değiştirme tesirinde yapı auxetic davranış sergilemektedir. En küçük gerilmeler ise, hücrelerin orta kısımlarındaki birleşim bölgelerinde oluşmaktadır. Şekil 7'de alt kısımda yer alan yer değiştirme ve gerilme dağılımlarında, çekme kuvveti etkisiyle yanal genişleme meydana gelmektedir. Böylece yapı çekme tesirinde auxetic davranışa uygun sonuçları vermektedir. Sandviç kompozit yapıda \%100 Al/ABS/PLA modellere kıyasla daha düşük yer değiştirme ve gerilme sonuçları oluşmaktadır. 
a)

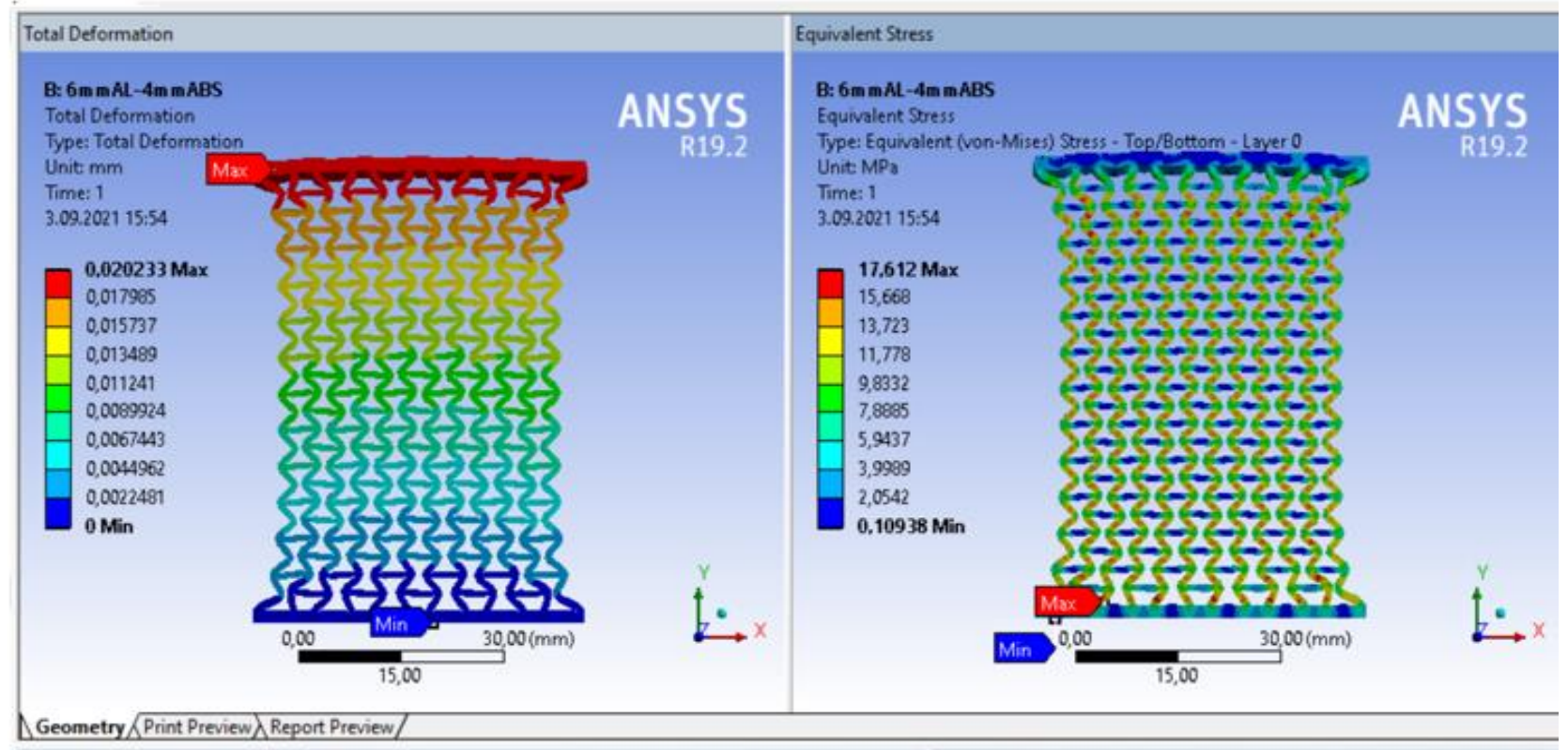

b)

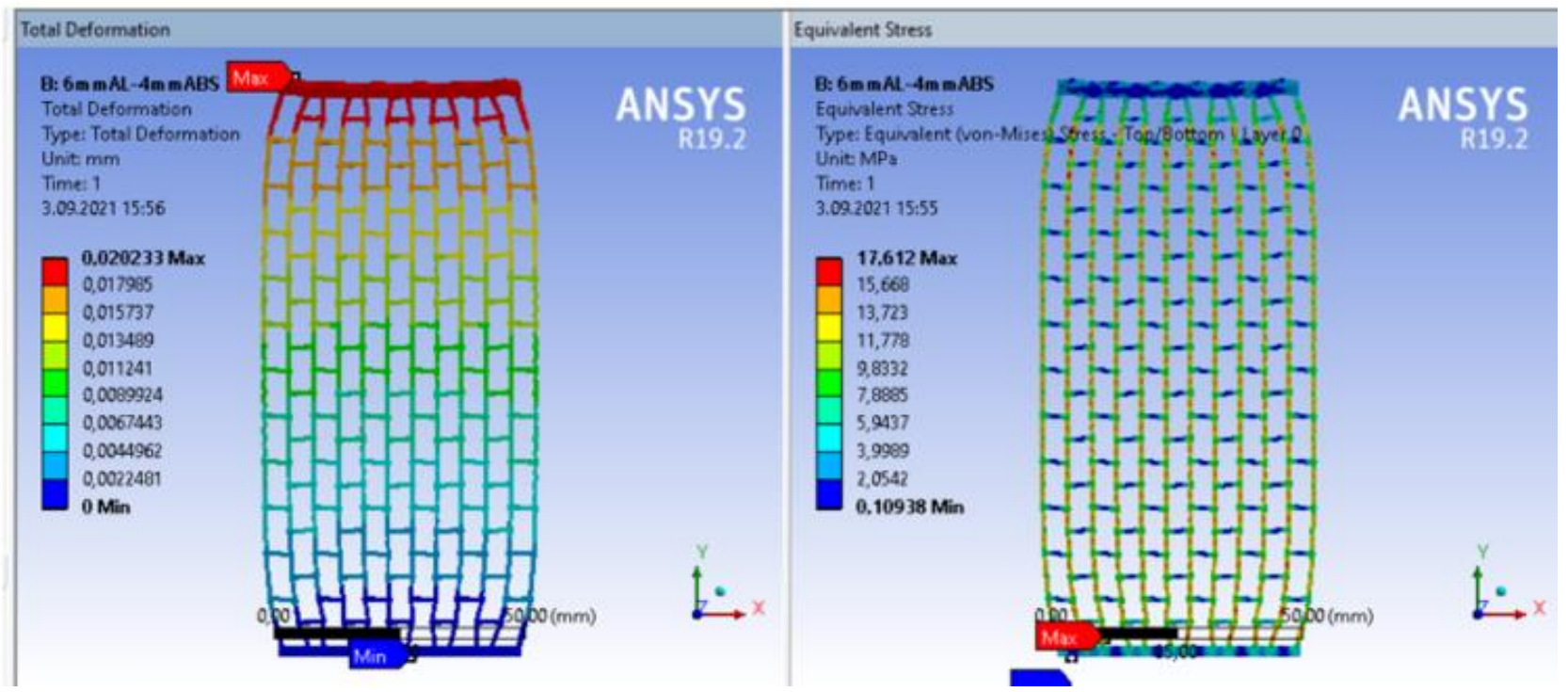

Şekil 7. Eksenel $1000 \mathrm{~N}$ kuvvet etkisindeki sırasıyla a) basma ve b) çekme tesirindeki 3 mm Al -4 mm ABS -3 mm Al olan model için analiz sonuçları

\subsection{5. $3 \mathrm{~mm} \mathrm{Al} \mathrm{-4} \mathrm{mm} \mathrm{PLA} \mathrm{-3} \mathrm{mm} \mathrm{Al} \mathrm{model}$}

Şekil 8'de, 3 mm Al-4 mm PLA-3 mm Al sandviç kompozit yapının a) -y ve b) +y yönünde uygulanan 1000 N'luk kuvvet tesirindeki statik analiz sonuçları görülmektedir. Burada lineer geometrik diziliş ve Re-entrant hexagon yapı itibariyle modelde basma kuvveti etkisi altında daralma görülmektedir. Yer değiştirme tesirinde yapı auxetic davranış sergilemektedir. En küçük gerilmeler ise, hücrelerin orta kısımlarındaki birleşim bölgelerinde oluşmaktadır. Şekil 8'de alt kısımda yer alan yer değiştirme ve gerilme dağılımlarında, çekme kuvveti etkisiyle yanal genişleme meydana gelmektedir. Böylece yapı çekme tesirinde auxetic davranışa uygun sonuçları vermektedir. Sandviç kompozit yapıda \%100 Al/ABS/PLA modellere kıyasla daha düşük yer değiştirme ve gerilme sonuçları oluşmaktadır. 
a)

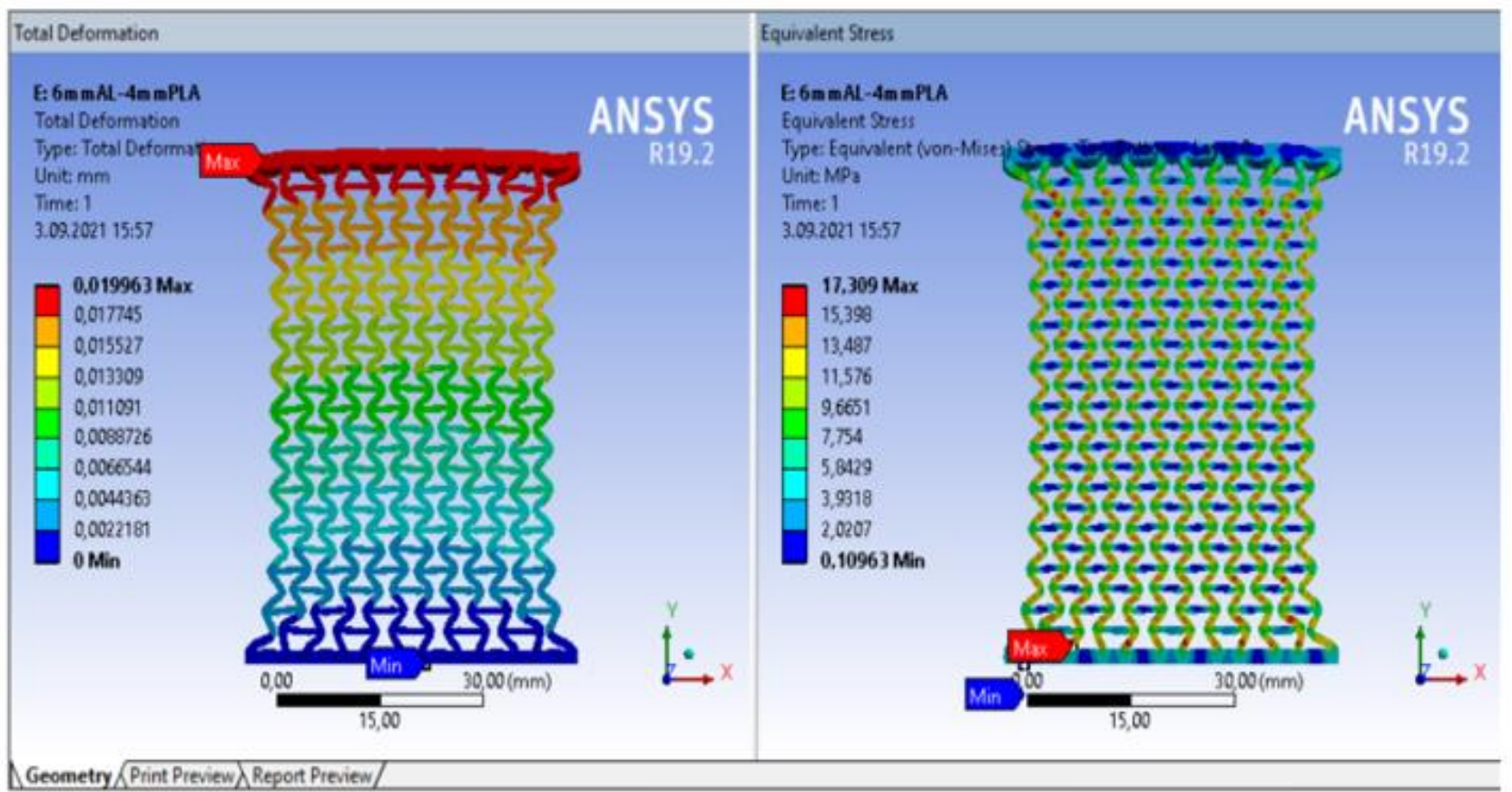

b)

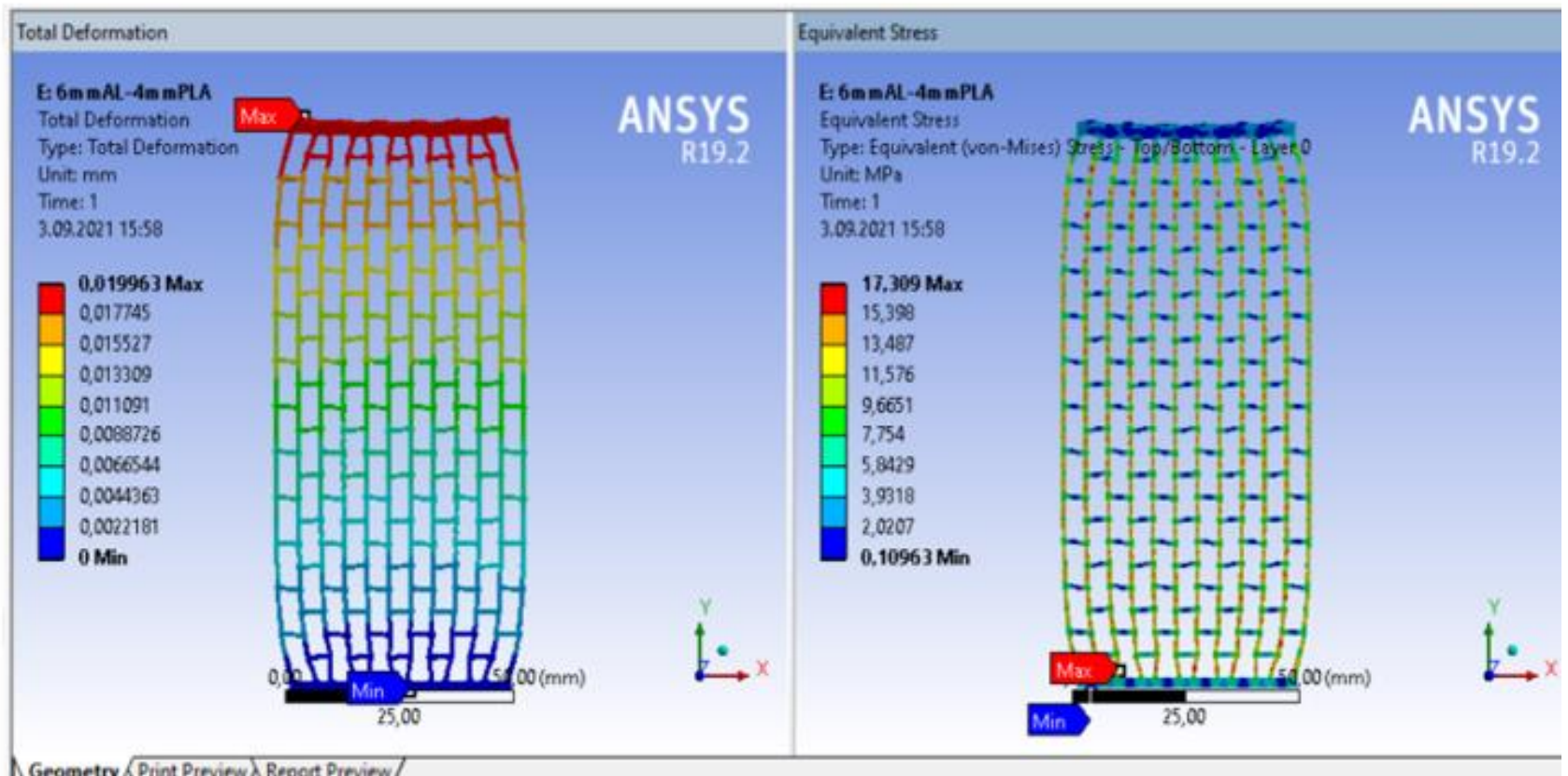

Şekil 8. Eksenel $1000 \mathrm{~N}$ kuvvet etkisindeki sırasıyla a) basma ve b) çekme tesirindeki $3 \mathrm{~mm} \mathrm{Al} \mathrm{-} 4 \mathrm{~mm}$ PLA -3 mm Al olan model için analiz sonuçları

\subsection{Analiz Sonuçlarının Karşılaştırılması}

Tablo 2.'de sandviç kompozit yapıların ve \%100 Al, \%100 ABS, \%100 PLA malzeme ataması yapılan modellerin analiz sonuçları gösterilmektedir. Kuvvet +y (çekme) ve -y (basma) yönünde $1000 \mathrm{~N}$ olarak uygulanmaktadır. Sonuçlarda yer değiştirme (mm) ve eşdeğer gerilme (MPa) değerleri ele alınmaktadır. Tablo 2.'de gösterilen 5 problemin analiz sonuçları neticesinde karşılaştırmalar yapılarak analiz sonuçlarına göre en uygun yapı belirlenecektir. 
Tablo 2. Yapısal Elemanların Analiz Sonuçları

\begin{tabular}{|c|c|c|c|c|c|}
\hline & & \multicolumn{4}{|c|}{1000 N Kuvvet } \\
\hline & Malzeme & $\begin{array}{l}\text {-y yönüinde } \\
\text { Yer } \\
\text { Değiştirme } \\
\text { (mm) }\end{array}$ & $\begin{array}{l}\text { +y yönünde } \\
\text { Yer } \\
\text { Değiştirme } \\
(\mathrm{mm})\end{array}$ & $\begin{array}{l}\text {-y yönünde } \\
\text { Eşdeğer } \\
\text { Gerilme } \\
\text { (MPa) }\end{array}$ & $\begin{array}{l}\text { +y yönünde } \\
\text { Eşdeğer } \\
\text { Gerilme } \\
\text { (MPa) }\end{array}$ \\
\hline 1. Problem & $\% 100 \mathrm{Al}$ & 0,017681 & 0,017681 & 22,86 & 22,86 \\
\hline 2. Problem & $\% 100 \mathrm{ABS}$ & 0,50945 & 0,50945 & 22,511 & 22,511 \\
\hline 3. Problem & $\% 100$ PLA & 0,35455 & 0,35455 & 22,539 & 22,539 \\
\hline 4. Problem & $\begin{array}{l}\text { Sandviç Kompozit Yapı (3 } \\
\text { mm Al-4mm ABS- } 3 \text { mm } \\
\text { Al) }\end{array}$ & 0,020233 & 0,020233 & 17,612 & 17,612 \\
\hline 5. Problem & $\begin{array}{l}\text { Sandviç Kompozit Yapı ( } 3 \\
\text { mm Al-4mm PLA-3 mm } \\
\text { Al) }\end{array}$ & 0,019963 & 0,019963 & 17,309 & 17,309 \\
\hline
\end{tabular}

1. Problem, \%100 Al'dan oluşan modelin statik analiz sonuçlarını göstermektedir. $1000 \mathrm{~N}$ 'lk basma ve çekme kuvvet tesirlerinde yer değiştirmenin $0,017681 \mathrm{~mm}$ ve eşdeğer gerilmenin $22,86 \mathrm{MPa}$ olduğu görülmektedir. 5 problem arasında, en düşük yer değiştirmenin ve en yüksek eşdeğer gerilmenin \%100 Al modelde oluştuğu söylenebilmektedir.

2. Problem, \%100 ABS'den oluşan modelin statik analiz sonuçlarını göstermektedir. 1000 N'lık basma ve çekme kuvvet tesirlerinde yer değiştirmenin $0,50945 \mathrm{~mm}$ ve eşdeğer gerilmenin $22,511 \mathrm{MPa}$ olduğu görülmektedir. En yüksek yer değiştirme \%100 ABS modellemede oluşmaktadır.

3. Problem, \%100 PLA'den oluşan modelin statik analiz sonuçlarını göstermektedir. 1000 N'lık basma ve çekme kuvvet tesirlerinde yer değiştirmenin $0,35455 \mathrm{~mm}$ ve eşdeğer gerilmenin 22,539 MPa olduğu görülmektedir. Eşdeğer gerilme sonuçlarına bakıldığında, ABS ile çok yakın sonuçlar çıkmasına rağmen, yer değiştirmede ABS'ye göre daha düşük sonuçlar elde edilmektedir.

4. Problem, 3mm Al-4mm ABS-3mm Al sandviç kompozit yapılı modelin statik analiz sonuçlarını göstermektedir. 1000 N'lık basma ve çekme kuvvet tesirlerinde yer değiştirmenin $0.020233 \mathrm{~mm}$ ve eşdeğer gerilmenin $17,612 \mathrm{MPa}$ olduğu görülmektedir.

5. Problem, 3mm Al-4mm PLA-3mm Al sandviç kompozit yapılı modelin statik analiz sonuçlarını göstermektedir. $1000 \mathrm{~N}$ 'lık basma ve çekme kuvvet tesirlerinde yer değiştirmenin $0,019963 \mathrm{~mm}$ ve eşdeğer gerilmenin 17,309 MPa olduğu görülmektedir. Tüm problemler arasında en düşük sonuçlar 5. Problemde gerçekleşmektedir.

Sonuçlar karşıllaştırıldığında; 1. Problem, 2. Problem ve 3. Probleme kıyasla sandviç kompozit yapılarda daha düşük sonuçlar oluştuğu söylenebilmektedir.

\section{Sonuç}

Bu çalışmada, negatif poisson oranlı davranış gösteren Re-entrant hexagon yapılı modellemenin çekme ve basma kuvvet tesirlerindeki statik davranışları incelenmiştir. Ayrıca bu geometrik yapıya 2 adet sandviç kompozit yapı entegre edilerek farklı kompozit malzeme yapılarındaki mekanik davranış sonuçları karşılaştırılmıştır. Negatif poisson oranlı oluşum sayesinde açığa çıkan; yüksek enerji absorbe yeteneği, sürtünme dayanımı, hafiflik, kopma dayanımı vb. avantajlar ile sandviç kompozit yapıdaki benzer avantajlar göz önünde bulundurularak bu iki yapının birbirine entegre edilmesi ile olumlu sonuçlar elde edilmiştir.

Tablo 2'de yer alan değerler karşılaştırıldığında; sandviç kompozit yapıların \%100 ABS, \%100 PLA, \%100Al modellerine kıyasla eşdeğer gerilmesinde ortalama \%24-25 oranında azalmanın gerçekleştiği söylenebilmektedir. En düşük sonuçlar ise, 5. Problemde yer alan 3mm Al-4mm PLA-3mm Al sandviç kompozit yapıda oluşmuş̧ur.

Yüksek mukavemet, hafiflik, maliyetin düşük olması ve üretim kolaylığı gibi büyük avantajlar ile elde edilen sonuçlar göz önünde bulundurulduğunda negatif poisson oranlı sandviç kompozit yapıların kullanılmasıyla, düşük sıcaklık etkisinde yüksek kuvvetlere karşı dayanım isteyen endüstriyel üretim alanlarına katma değer oluşturmak şüphesizdir. 


\section{Referanslar}

Berwind, M. F., Kamas, A., Eberl, C. (2018). A Hierarchical Programmable Mechanical Metamaterial Unit Cell Showing Metastable Shape Memory, Advanced Engineering Materials, 1800771, 1-6.

Boğa, C., Seyedzavvar, M., Zehir, B. (2021). Experimental Investigation on the Effects of Internal Architecture on the Mechanical Properties of 3D Printed PLA Components, European Journal of Science and Technology Special Issue 24; $119-124$.

Ceyhun, V., Turan, M., (2003). Tabakalı Kompozit Malzemelerin Darbe Davranışı. Ege Üniversitesi, Mühendislik Fakültesi, Makine Mühendisliği Bölümü, İzmir, Türkiye, Cilt: 44, sayfa aralığı: 35 - 41.

Dirim, A., (2021). ABS ve PLA Karşılaştırması-Farkları. (https://www.tasarimdanimalata.com/abs-ve-pla-karsilastirmasi-farklari/)

Ermeydan, M.A. ve Aykanat, O., (2019). Pla/Boynuz Biyokompozitlerin Termal Ve Mekanik Özelliklerinin İncelenmesi. Engineering Sciences(NWSAENS), 1A0444, 2019; 14(4):226-231. doi: http://dx.doi.org/10.12739/NWSA.2019.14.4.1A0444

Imak, A., Solmaz, M.Y., Topkaya, T., (2016). Tabakalı Hibrit Kompozit Malzemelerin Yorulma Davranışlarının Analizi, El-Cezerî Fen ve Mühendislik Dergisi 2016 3(3); 448-458.

Ingrole, A., Hao, A., Liang. R. (2017). Design and modeling of auxetic and hybrid honeycomb structures for in-plane property enhancement, Materials and Design, 117, 72-83.

Işıltan, A., (2017). Negatif Poisson Oranın Sahip Bir Mikro-Kafes Yapının Tasarımı-Analizi. İstanbul Teknik Üniversitesi Fen Bilimleri Enstitüsü, Yüksek Lisans Tezi, İstanbul, sayfa sayısı: 93.

Jiang, y., Li, Y. (2018). 3D Printed Auxetic Mechanical Metamaterial with Chiral Cells and Re-entrant Cores, Scientific Reports, 8:2397, 1-11.

Korkut, S., (2019). Poisson Oran1. (https://www.serdarkorkut.com/2017/05/26/poisson-orani-nedir/)

Lakes, R. J. (1987). “Foam Structures with a Negative Poisson’s Ratio”, Sience, 235, 1038-1040.

Öztop, B., Gürbüz, M.,(2017). Investigation of Properties of Composites Produced by Reinforcement Graphene Matrix Obtained from Waste Aluminium. International Journal of Multidisciplinary Studies and Innovative Technologies, $2017,1(1): 4-8$.

Potoğlu, U., (2012). Sandviç Kompozit Plakaların Darbe Davranışları. Dokuz Eylül Üniversitesi Fen Bilimleri Enstitüsü, Yüksek Lisans Tezi, İzmir, sayfa sayısı: 83.

Sarvestani H. Y., Akbarzadeh, A., Mirbolghasemi, A., Hermenean, K. (2018). "3D printed meta-sandwich structures: Failure mechanism, energy absorption and multi-hit capability”, Materials \& Design, 160, 179-93.

Şen, N., Şengül, Ö., Uygur İ.,(2020). Geri Dönüşümü Yapılmış PP ve ABS Prototip Malzemelerin Bazı Mekanik ve Termal Özelliklerinin İncelenmesi. Düzce Üniversitesi Bilim ve Teknoloji Dergisi, 8 (2020) 246-257. doi: 10.29130/dubited.655553

Uzun, M. (2017). Negatif Poisson Oranına Sahip (Auxetic) Malzemeler Ve Uygulama Alanları, TMMOB Tekstil Mühendisleri Odası - Tekstil ve Mühendis, 17, 13-18.

Yu, X., Zhou, J., Liang, H., Jiang, Z., Wu, L. (2018). Mechanical metamaterials associated with stiffness, rigidity and compressibility: A brief review, Progress in Materials Science, 94, 114-173.

Yuan, S., Chua, C. K., Zhou, K. (2019). 3D-Printed Mechanical Metamaterials with High Energy Absorption, Advanced Materials Technologies, 4(3), 1800419. 